FREEDOM STRUGGLES 



\title{
FREEDOM STRUGGLES
}

\author{
African Americans and World War I
}

Adriane Lentz-Smith

HARVARD UNIVERSITY PRESS

Cambridge, Massachusetts

London, England

2009 
Copyright (C) 2009 by the President and Fellows of Harvard College All rights reserved

Printed in the United States of America

Library of Congress Cataloging-in-Publication Data

Lentz-Smith, Adriane Danette.

Freedom struggles : African Americans and World War I / Adriane Lentz-Smith. p. $\mathrm{cm}$.

Includes bibliographical references and index.

ISBN 978-0-674-03592-8 (alk. paper)

I. World War, 1914-I918-Participation, African American. 2. United States. Army-African American troops-History-2oth century. 3. African American soldiers-History-History-2oth century. 4. African Americans-Social conditions—2oth century. 5. Racism-United States-History—2oth century.

6. United States-Race relations. I. Title.

D639. $\mathrm{N}_{4} \mathrm{~L}_{4} 62009$

940.4'03-dc22 2009017348 
To Mom and Dad, with love.

And to Zora, whose story is just beginning. 
